\title{
Porosity Control and Mechanical Properties of Porous Ceramic Material from Plered Region
}

\author{
Sulistyo $S .{ }^{1, *}$, Rizky $^{2}$ \\ ${ }^{1,2}$ Departemen Teknik Mesin, Fakultas Teknik, Universitas Diponegoro \\ Jl. Prof. Sudharto, SH., Tembalang-Semarang 50275, Telp. +62247460059
}

\begin{abstract}
Plered region is located in around Purwakarta area, west java, Indonesia. Plered is famous as ceramic product especially ceramic tiles, decorative ceramics, tableware and roof tiles. This paper investigated the manufacturing of porous ceramic from Plered and evaluated the mechanical properties especially bending strength. The investigation include the controlling of porosity using pore former during manufacturing, investigation of chemical composition and evaluated the fracture strength using bending test. Evaluation of porosity ceramic product use an archimedes method and scanning electron microscopy and the bending strength of porous ceramic using three point bending test. The porous ceramic was tailored by using compaction process and sintering process at temperature of $1250 \mathrm{C}$, the pore former (rice starch) was added on the material ceramic to control of porosity. The bending strength use standard ASTM C1161-13 which sample has cross section of $6 \times 8 \mathrm{~mm}^{2}$ and $90 \mathrm{~mm}$ long. The results show that the porosity increases with the number of pore formers in a mixture of clay, the porosity of sinter ceramic was 7 vol $\%, 12 \mathrm{vol} \%, 17 \mathrm{vol} \%$ at using pore former $5 \mathrm{wt} \%, 15 \mathrm{wt} \%$ and $25 \mathrm{wt} \%$ respectively. The bending strength of sinter ceramic was declined with increasing porosity. The bending strength of sintered ceramic was $58 \mathrm{MPa}$, $49.5 \mathrm{MPa}$ and $34.7 \mathrm{MPa}$ at porosity of $7 \mathrm{vol} \%, 9 \mathrm{vol} \%$ and $14 \mathrm{vol} \%$ respectively.
\end{abstract}

\section{Introduction}

Plered region is located in around Purwakarta area, west java, Indonesia. Plered is famous as ceramic product especially ceramic tiles, decorative ceramics, tableware and roof tiles [1]. Currently, the function of ceramic plered can be used for engineriing material such as ceramic filter, thermal barier materials and catalytic materials [2-4]. Fabrication of porous ceramic can be done by using compaction process and continued by sintering process [3]. The compaction can be use to increase green compact strength and certain shape while the sintering process can increase the strength porous body due to forming bond of interparticle ceramic occurs.

*Corresponding author: listyo2007@gmail.com 
The porous ceramic can be controlled by adding pore former likes a rice starch. The rice starch will burn during sintering process to form void as pore in the ceramic body. The starch must be controlled to obtain the certain porosity of ceramic body. The During operation of porous ceramic sometimes the body should support the certain load. The load must be capable to sustain in the ceramic body. The strength of porous ceramic trend to decrease with the increaasing of porosity [5]. The porous ceramic strength should be appropriate with the environment condition. For example, the range of ceramic porous as an electrode of solid oxide fuel cell (SOFC) is limited between $20-60 \mathrm{vol} \%$ [6-7]. This condition is to serve the electrode can be function well as load support, catalytic substrate and a good gas transport [7].

\section{Materials and Methods}

Plered bowlder is dried in the room temperature. The bowlder was crushed by using mortar into small particles. The small particles (powders) were dried in oven at temperatur $110^{\circ} \mathrm{C}$ for 2 hours. The dried powders were sieved by using mesh size of 100 . The pore former used local rice starch of 100 mesh size. Manufacturing of bending strength specimen, Plered powders was added rice starch as pore former. The content of rice starchs in the Plered Powders are $5 \%, 10 \%, 25 \%$ by weight respectively. The water was used as binder. The compaction use load of $15 \mathrm{kN}$. The sintering temperature of specimen was controlled at $1250^{\circ} \mathrm{C}$ using holding time of 1 hour. The final size of specimens were smoothed by using sand paper to accordance standard ceramic bending test ASTM 1161 13. The size of bending test specimen is $6 \times 8 \mathrm{~mm}^{2}$ and $90 \mathrm{~mm}$ long using Wance hydraulic universal testing machine (China). The composition of Plered powder was tested by ICPAES, optical emission spectroscopy (Japan), the specimens porosity was done by using Archimedes metods and the bending strength was tested by universal machine test

\section{Result and Discussion}

Chemical composition of Plered powder was presented in table 1 . The weight procentage of chemical content of $\mathrm{Si}$ (silicone), $\mathrm{Al}$ (aluminum), $\mathrm{Fe}$ (iron), $\mathrm{K}$ (Kalium), $\mathrm{Mg}$ (magnesium), $\mathrm{U}$ (uranium) and others are $49.50 \%, 44.75 \%, 3.25 \%, 1.00 \%, 0.53 \%, 0.46$ $\%$ and balance respectively. The highest content is component of $\mathrm{Si}$ and the lowest is $\mathrm{U}$.

Table1. Chemical composition of Plered powder by weight precentage

\begin{tabular}{|l|c|c|c|c|c|c|c|}
\hline & $\mathrm{Si} \%$ & $\mathrm{Al} \%$ & $\mathrm{Fe} \%$ & $\mathrm{~K} \%$ & $\mathrm{Mg} \%$ & $\mathrm{U} \%$ & others \\
\hline Plered powders & 49.50 & 44.75 & 3.25 & 1.00 & 0.53 & 0.46 & balance \\
\hline
\end{tabular}

Tablel show the contents of $\mathrm{Si}, \mathrm{Al}, \mathrm{Fe}, \mathrm{K}, \mathrm{Mg}$, the Plered powder can be classified as kaolin clay $[8,9]$. These composition of Plered powder can affect the temperature heating during sintering process especially the component of $\mathrm{Al}, \mathrm{Si}$ and $\mathrm{Fe}$ content $[1,4,9]$. The higher of $\mathrm{Al}$ can increase the temperature sintering to get the strength of Plered substrate [9]. The temperature sintering was done at temperature of $1250^{\circ} \mathrm{C}$ with soaking time of 1 $\mathrm{hr}$. This temperature is appropriate to increase the strength of the green compact without a damage of the specimen. The Figure 1 shown the specimen of the bending test. It seen that the specimen has been succesfully to be form into specimen bending test standard without crack and warpage. The size of the specimen is $6 \times 8 \mathrm{~mm}^{2}$ and $90 \mathrm{~mm}$ long. The sintering temperature of $1250^{\circ} \mathrm{C}$ with soaking time of $1 \mathrm{hr}$ are capable to increase the strength of the green compact. The diffusion process of the inter ceramic powder occured during sintering 
process [4]. The temperature sintering of $1250 \mathrm{C}$ can be used as reference of the plered ceramic process.

The bending test was done by universal testing machine. The size of the specimen must be followed the standard ASTM 1161-13.

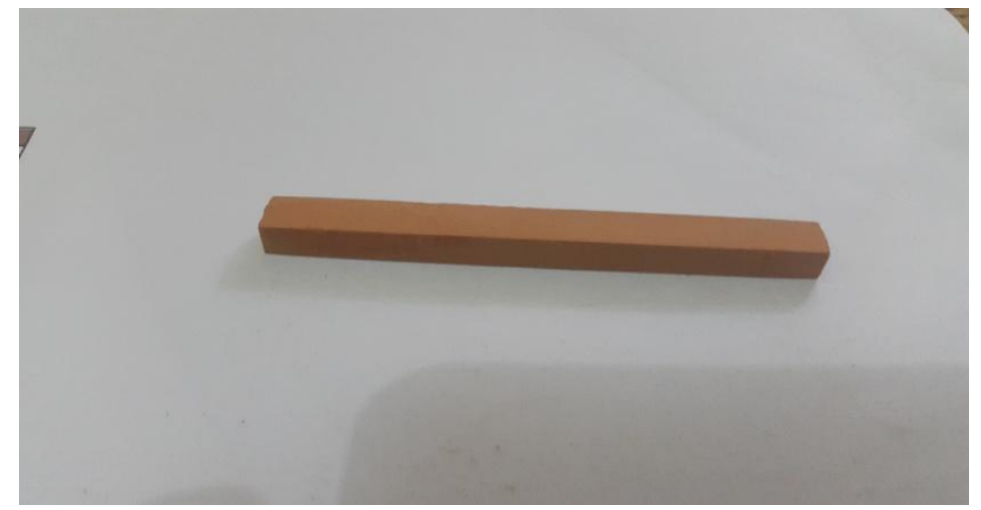

Fig. 1. The specimen of bending test

Figure 2 shows the relation between porosity and bending strength. The porosity of specimen can be controlled by adding of pore former (rice starch). The pore former will escape from the specimen during sintering process to form the void. The void in the specimen was called a pore $[3,5]$. The adding pore former in the substrate can increase the value of porosity specimen [2,7]. The pore former increase in the substrate, during sintering process, the pore former will be vanished to form more porosity.

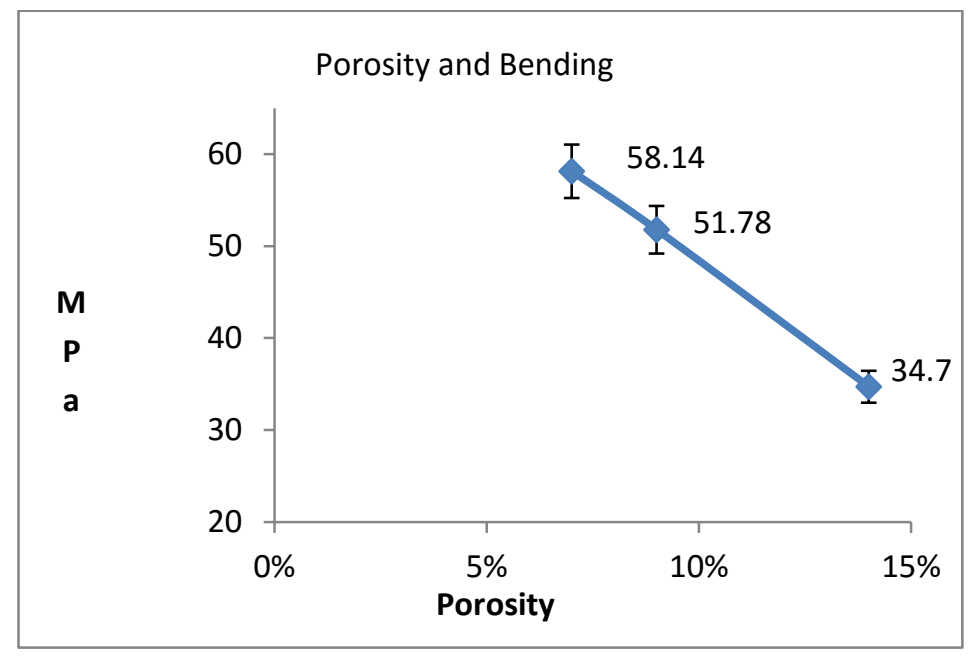

Fig. 2. Relation between porosity and bending strength

The value of specimen porosity will increase.. The specimen of bending strength of the plered clay was controlled by the porosity during testing.

The figure 2 show the relation between porosity and the bending strength. At porosity of $7 \mathrm{vol} \%$, the bending strength is $58.14 \mathrm{MPa}$, while at porosity of $14 \mathrm{vol} \%$, the value of bending strength is $34.7 \mathrm{MPa}$. The increase of porosity in the body will decline the bending strength [5]. The increase of the porosity can be easier to form big void due to an external load. The external load will be easier to merge small void into big void. This big void is as source of the crack initiating that will decline the strength. The porosity increase, the 
strength of the specimen decline [5]. This information can be used as the guidance of the filter product manufacturing process in the future.

Figure 3 show the microstructure of porous ceramic. The observation use scanning electronic microscopy (SEM). From the picture can be shown the particle size and the pore size.

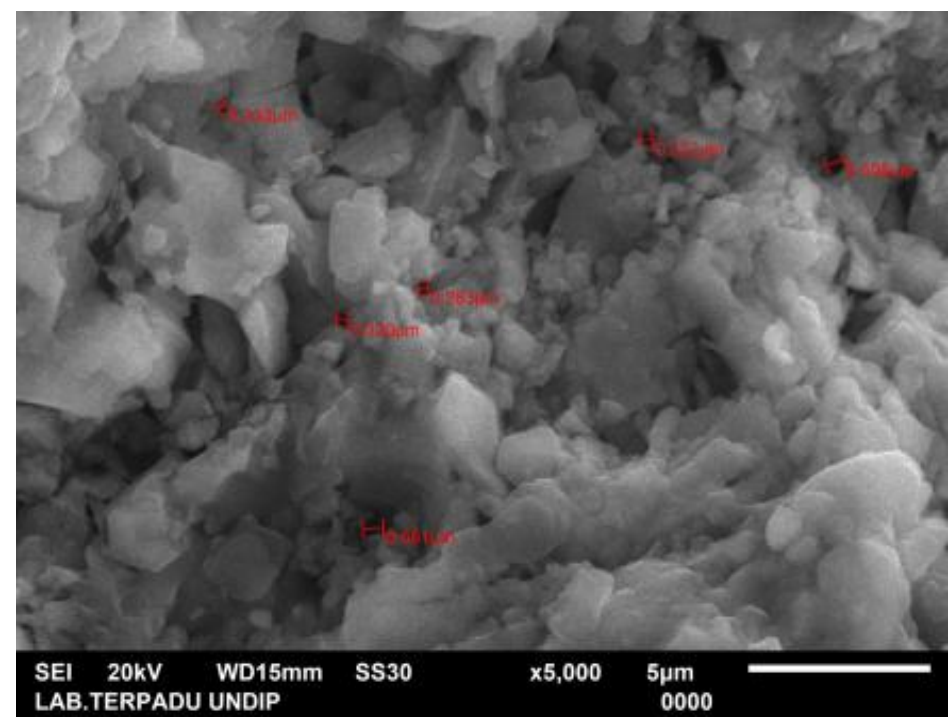

Fig. 3. Microstructure of ceramic plered using SEM

The distribution of of the pore is relatively homogen. The size pore is relatively small around $0.28 \mu \mathrm{m}-0.54 \mu \mathrm{m}$. Generally the pore morphology that was formed in the specimen is randomly. The temperature sintering of $1250^{\circ} \mathrm{C}$ can consolidate the clay particles. It can be seen in the Fig.3. The strength of porous material can be controlled by adding pore former as shown the figure 2 . The bonding of interpartcles is be enough to give the strength of specimens [2,7].

\section{Conclusion}

The conclusion can be obtained after the discussion. The rice starch local can be used as pore former to make the pore material, the increase rice starch can increase the porosity. The bending strength of the pore material is affected by the sum of porosity in the materials. The incresing of pore material will decline the bending strength. The temperature of $1250^{\circ}$ can be use as sintering temperature to get consolidation of the Plered clay.

\section{Reference}

[1] A. K. Pakpahan, Procedia Economics and Finance, vol.4, International Conference on Small and Medium Enterprises Development with a Theme (ICSMED 2012), pp. 44-53 (2012)

[2] O. Yu, Materials Science is a copyright of Springer, vol. 51, no. Ukraina, pp. 847-853 (2016)

[3] Chao wang, Ceramic International, vol. 42, pp. 14222- 4227 (2016)

[4] David Obada, Applied Clay Science, Vols. 132-133, pp. 194-204 (2016)

[5] Meille, Journal of the European Ceramic Society, vol. 32, pp. 3959- 3967 (2012)

[6] Keegan C. Wincewics, Journal of Power Sources, vol. 140, pp. 280-296 (2005)

[7] S. Sulistyo, S. Arifin, S. Mahzan ,International Journal of Science and Engineering, vol. 4, no. 1, pp. 30-33, 2013. 
[8] Rowse, Clays and Clay menerals, Pergamon Press, vol. 23, pp. 310-317 (1975)

[9] J.C.F. Segura, et all ,Applied Clay Science, vol. 146, pp. 264-269 (2017) 